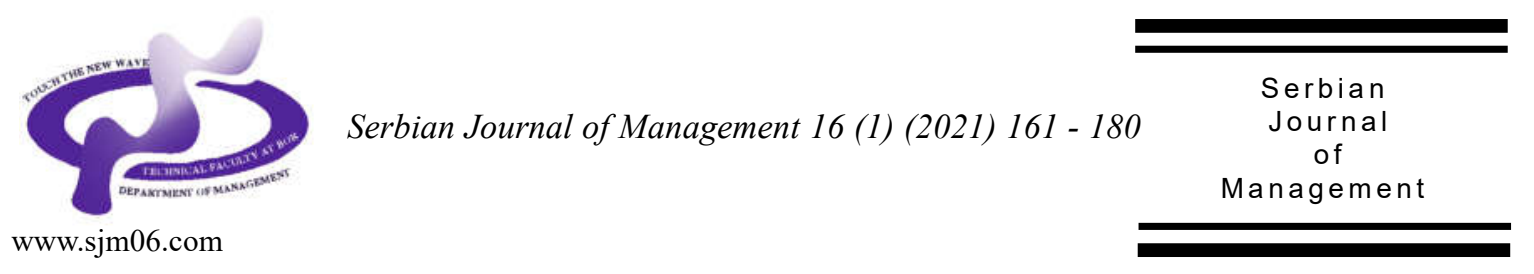

\title{
THE INFLUENCE OF ORGANIZATIONAL CULTURE ON SUPPLY CHAIN INTEGRATION
}

\author{
Slobodan Aćimovića ${ }^{a}$ Veljko M. Mijuškovića ${ }^{*}$ and Ana Todorović Spasenićb

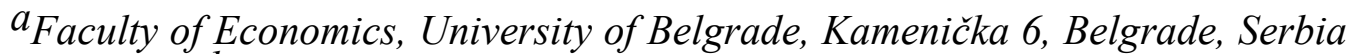

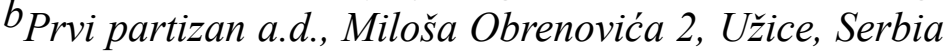

(Received 23 December 2020; accepted 28 February 2021)

\begin{abstract}
A team of employees that strives for the realization of a common goal is what every company needs, and the success of business depends on the way of functioning and thinking of that team. The organizational culture shapes the way employees think, react and behave. The business practice of companies in the Republic of Serbia has shown that the organizational culture oriented to employees, action and challenges is an important determinant of improving all business performance indicators, including the supply chain integration, which is the main topic of analysis within this paper. The dimensions of organizational culture affect internal integration, integration with customers and integration with suppliers, determining the generation of the key goal of supply chain management which refers to the delivery of the right product, at the right place, at the right time and at reasonable costs.
\end{abstract}

Keywords: organizational culture, supply chain integration, Republic of Serbia

\section{INTRODUCTION}

Developed organizational culture is an excellent motivator for employees. Constant and dedicated development of organizational culture stimulates employees to greater commitment in the workplace, teamwork and improving the quality of products and services thus improving general business performance. The dimensions of organizational culture determine the behavior of employees and their teamwork, which directly affects the coordination and teamwork among organizational parts of the company, but also the team commitment of employees to improve business quality and generate/maintain long-term partnerships with suppliers and customers.

* Corresponding author: veljko.mijuskovic@ekof.bg.ac.rs

DOI: 10.5937/sjm16-30007 
The subject of research within this paper is the analysis of the impact of organizational design dimensions on supply chain integration, as one of the key qualitative indicators of business performance. The aim of the study is to identify which of the dimensions has the greatest positive or negative impact on each of the levels of supply chain integration: internal integration, integration with customers and integration with suppliers. The first part of the paper is a review of the theoretical aspect of organizational culture and supply chain integration, as well as previous research results in the field of their interdependence. The research methodology, as the second part of the paper, is defined on the basis of relevant literature, with a focus on the fullest possible achievement of the set goals of the paper. The results of descriptive, correlation and regression statistical analysis, presented within the third part of the paper, allow a detailed analysis of the interdependence of variables presented in the initial research model. The fourth part of the paper presents concluding remarks on the issue of initial research hypotheses, based on the results of statistical analyzes. The final, fifth part of the paper indicates the scientific and practical contribution of the research, with the identification of the limitations of the paper and proposals for their correction in future research on this topic.

\section{LITERATURE REVIEW}

\subsection{Organizational culture and its dimensions}

Roger Harrison defined organizational culture as "the way we work in our business environment" (Harrison \& Stokes, 1992). It is a system of assumptions, beliefs, values and norms of behavior that the members of an organization have developed and adopted through shared experience (Janićijević, 2008; Denison et al., 2012; Polychroniou \& Trivellas, 2018). Very often the term "organizational culture" is equated with the term "organizational climate". Organizational climate can be most simply defined as a set of attitudes, behaviors and rules that are widespread in the organization and last for a long time. It is usually associated with the prevailing atmosphere surrounding the organization, the level of morale and the strength of the sense of belonging, care and goodwill among members (Sikavica et al., 2008). It is an integral part of the organizational culture and explains how the organization and its employees connect and interact (Kaur, 2009).

Many authors consider the organizational culture to be one of the key sources of sustainable competitive advantage. Jay Barney pointed out that the sustainability of the superior financial performance of successful global companies such as IBM, Procter \& Gamble, and McDonalds is based on the managerial values and beliefs embedded in the organizational culture of these companies (Barney, 1980). Business practice presented a strong link between successful financial performance and precisely defined managerial values that define the way of doing business, primarily values related to the way employees, suppliers, customers and other stakeholders are treated (Prajogo \& Mc Dermott, 2005; Yilmaz \& Ergun, 2008; Cameron \& Quinn, 2011). The results of the research crystallized a focus on development, reward system, centralized/decentralized decision/control and teamwork of employees 
as dimensions of organizational culture with the greatest impact on survival and market success, in conditions of fierce competition (Koufteros et al., 2005; Stock et al., 2007; Wong et al., 2011; Huo et al., 2014; Cao et al., 2015).

It can be concluded that the organizational culture determines the character of the company. It involves decision-making and problem-solving of the organization and has a major impact on goals, cash, and type of action (Walters et al., 1989; Sokro, 2012; Ponnu \& Hassan, 2015; Kim \& Chang, 2019). It is considered to be one of the key sources of employee's motivation, satisfaction and dissatisfaction (Badawy et al., 2016; Krajcsák, 2018; Kucharska \& Bedford, 2019; Utami \& Sitohang, 2019). Simply put, the organizational culture is related to all aspects of the organization. Good knowledge of the elements of the organizational culture and their harmonization with the goals of the organization are key prerequisites for successful business and maintaining a competitive advantage within the markets.

\subsection{Levels of supply chain integration}

For the survival and success of companies in the market, in conditions of fierce competition, it is important to effectively integrate the process along the entire supply chain. Supply chain integration is one of the key qualitative indicators of company performance (Bagchi et al., 2005; Lee et al., 2007; Danese \& Romano, 2011; Kim, 2013; Wiengarten et al. 2016; Chaudhuri et al., 2018). The importance of process integration along the entire distribution chain was precisely defined by Simchi-Levi and Kaminsky in their definition of supply chain management (Simchi-Levi et al., 2003):
"Supply chain management is a set of harmonized approaches to the integration of suppliers, manufacturers, warehouses and stores in such a way that the right quantity of products is produced and delivered, to the right locations, at the right time, with minimization of costs in the delivery system and with a certain level of service, ie. satisfaction of consumer requirements."

Within the structure of the supply chain, it is important to precisely determine who the participants are, what their resources are, what their potentials are, where they are located, what processes take place within the chain, how goods, information and financial flows are realized etc. The authors in the field highlight three levels of integration essential to establishing efficient and effective supply chain management (Cao et al., 2015; Chan et al., 2015; Cheng et al., 2016; Tarifa-Fernandez \& DeBurgos Jiemenez, 2017; Pakurar et al., 2019):

-Internal integration - integration of processes in the company;

-Integration with customers, with a focus on building long-term partnerships and

-Integration with suppliers, with a focus on building long-term partnerships.

Internal integration, as the level of supply chain integration, is focused on the integration of processes within a particular enterprise. The goal of this level of integration is to produce a quality product through teamwork of organizational parts of the company, with minimal costs (Cao et al. 2015; Qi et al., 2017; Roscoe et al., 2020). Efficient internal integration contributes to the reduction of inventory prices thanks to the fast and efficient response to customer requests and the adjustment of production to these requirements. By better production planning, the company realizes lower costs, which is the result of successful management 
of material flows through the production process.

Customer integration is the level of supply chain integration that is focused on building long-term partnerships with customers. This level actually reflects the importance of customer relationship management for establishing efficient and effective supply chain management. The efficiency of this level of integration is measured by reducing the cost of attracting new customers, increasing the number of long-term customers, reducing sales costs, increasing customer profitability and increasing customer loyalty (Alshurideh et al., 2019; Kumar, 2020; Rezaei et al., 2020; Ullah \& Narain, 2020). Respecting the requirements and needs of customers, with a quick and efficient response to their comments, represents the key to generating the previously listed goals.

Supplier integration, as the level of supply chain integration, presents the success of companies in building long-term partnerships with suppliers, which is one of the key goals of supplier relationship management, an integral part of supply chain management (Forkmann et al., 2016; Teller et al., 2016; Amoako-Gyampah et al., 2019). The benefits that the company seeks to generate by building long-term partnerships with suppliers are: fast and efficient delivery of products/raw materials/services of agreed quality, compliance with requirements, cooperation in improving product quality, fast and efficient exchange of information, adoption of a common value system (Jambulingam et al., 2011, Dubey et al., 2019 ) etc. Each of the previously listed benefits is the result of building business cooperation based on correctness and trust, which results in satisfaction and loyalty of both business partners.

\subsection{Interdependence of organizational culture and supply chain integration}

The interdependence of organizational culture and supply chain integration has been the subject of research by a large number of authors over the last ten years (Braunscheidel et al., 2010; Yunus \& Tadisina, 2010; Cao et al., 2015; Jacobs et al., 2016; Mandal, 2017; Sung \& Kim, 2019; Nguyen et al., 2020). One group of research is based on observing the dimensions of organizational culture- focus on organization, reward system, hierarchical dimensions and teamwork (Denison \& Spreitzer, 1991; Stock at al., 2007; Zu at al., 2010; Shih \& Huang, 2010), while the second group reclassified the previously listed dimensions into four types of organizational culture- development culture, rational culture, hierarchical culture and group culture (Gregory et al., 2009; Yunus \& Tadisina, 2010; Hartnel et al,. 2011; Mandal, 2017). Both research groups "measure" organizational culture in a similar way, with similar findings, because the four types of organizational culture actually reflect the representation of each of the dimensions of organizational culture in the companies that were the subject of the research. What all studies have in common is the emphasis that organizational culture affects all levels of supply chain integration, which directly reflects on the level of performance achieved, primarily profitability and sales volume.

In a 2015 study, Cao and co-authors explained in detail that defining the dimensions of organizational culture actually determines the specifics of four types of organizational culture - developmental culture, rational culture, hierarchical culture and group culture (Cao et al., 2015). In the 
study, they mentioned the attitudes of researchers on the dimensions of organizational culture (counted research on this topic until 2015) and stressed that they similarly "measure" organizational culture, using findings that reflect the representation of each dimension of organizational culture in surveyed companies. The results of the research showed that development culture, rational culture and group culture have a positive impact on internal integration, integration with suppliers and integration with customers, as levels of supply chain integration. Hierarchical dimensions, more precisely organizational cultures dominated by centralized control and decision-making, have a negative impact on each of the levels of supply chain integration.

In a 2016 study, Jacobs, Yu and Chavez investigated the impact of internal communication and employee satisfaction on supply chain integration (Jacobs et al., 2016). The authors, surveying 214 manufacturing companies in China, concluded that the dimensions of organizational culture determine the effectiveness of communication and employee satisfaction, which directly affects the efficiency of internal integration, especially the flow of materials, information and money. Mandal in a 2017 study confirms these conclusions, emphasizing that all dimensions of organizational culture determine the resilience of the supply chain of any enterprise (Mandal, 2017). In a 2019 study, Sung and Kim, researching the business practices of Korean companies, concluded that the resilience of the supply chain to environmental uncertainties is significantly determined by organizational culture and its dimensions. In the same year, Mary Porter published a study which showed that companies with a culture of adhocracy achieve the greatest success in the field of efficient integration of all levels of the supply chain (Porter, 2019). It is an organizational culture characterized by the encouragement of individual initiatives and autonomy, which influences employees to be willing to take risks, dynamic, innovative and creative.

The 2020 study, based on the business practices of chemical companies in Vietnam, crystallized the moderating role of organizational culture in the impact of corporate entrepreneurship on business performance and supply chain integration as one of the indicators of business performance (Nguyen et al., 2020). In the 2020 study, Ullah and Narin also highlighted the significant impact of organizational culture on customer integration and customer relationship management, which is directly reflected in improving business performance levels (Ullah \& Narin, 2020). Both studies demonstrated the way in which organizational culture determines the style of enterprise management and the way in which it responds to changes in the environment, with the aim of survival and success in the market in conditions of fierce competition.

It can be concluded that previous researches on the interdependence of organizational culture and supply chain integration have proven the existence of a significant correlation between these variables. The authors observe in very similar ways the influence of organizational culture dimensions on each of the levels of supply chain integration, emphasizing the importance that this interdependence has on the level of business performance, survival and success of any company in the market. Simply put, organizational culture has so far crystallized as an important predictor of generating an efficient supply chain of 
companies in the domain of any sector of the economy.

\section{RESEARCH METHODOLOGY}

In order to identify the potential impact of the organizational culture on supply chain integration and to determine the dimension that contributes the most to internal integration, integration with suppliers and customers, an empirical study was conducted using a survey method. The research included 328 small, medium and large companies in the territory of the Republic of Serbia. The collection of primary data on the basis of the questionnaire was performed during May and June 2020.

The baseline model and research hypotheses were defined based on relevant literature sources (Sahay, 2003; Koufteros et al., 2005; Stock et al., 2007; Naor et al., 2008; Yunus \& Tadisina, 2010; Wong et al., 2011; Cao et al., 2015; Jacobs et al., 2016; Mandal, 2017; Porter, 2019; Muhlis \& Prateep, 2019; Kumar, 2020; Rezaei et al., 2020; Ullah \& Narain, 2020). The initial model is shown within Figure 1, and the initial hypotheses (which will be confirmed or rejected after the statistical analyzes are conducted) are:

H1: Development orientation, as a dimension of organizational culture, affects the supply chain integration (internal integration, integration with suppliers and integration with customers).

H2: The reward system, as a dimension of organizational culture, affects supply chain integration (internal integration, integration with suppliers and integration with customers).
H3: Hierarchy, as a dimension of organizational culture, influences supply chain integration (internal integration, supplier integration and customer integration).

H4: Teamwork, as a dimension of organizational culture, influences supply chain integration (internal integration, supplier integration and customer integration).

H5: Organizational culture is an important predictor of generating supply chain integration efficiency.

The questionnaire consisted of three parts. The first part aimed at identifying the companies that participated in the research: the size of the company, the experience in doing business, the seats classified according to the statistical regions of the Republic of Serbia and the economic sector to which the company specifically belongs to. In the second part of the questionnaire, the representative of a particular company rated the dimensions of organizational culture with grades 1-5, i.e. through the Likert five-point scale, where grade 1 means "absolutely disagree with the statement" and grade 5 "absolutely agree with the statement".

Observing the structure of the sample in Table 1, it can be stated that the sample includes the most medium-sized enterprises (46\%), followed by small (29\%) and large enterprises $(25 \%)$. The sample structure is dominated by companies with a business history of over 20 years $(38 \%)$. When it comes to the economic sector to which companies belong to, the largest share of companies was recorded in the manufacturing sector $(50 \%)$, followed by 


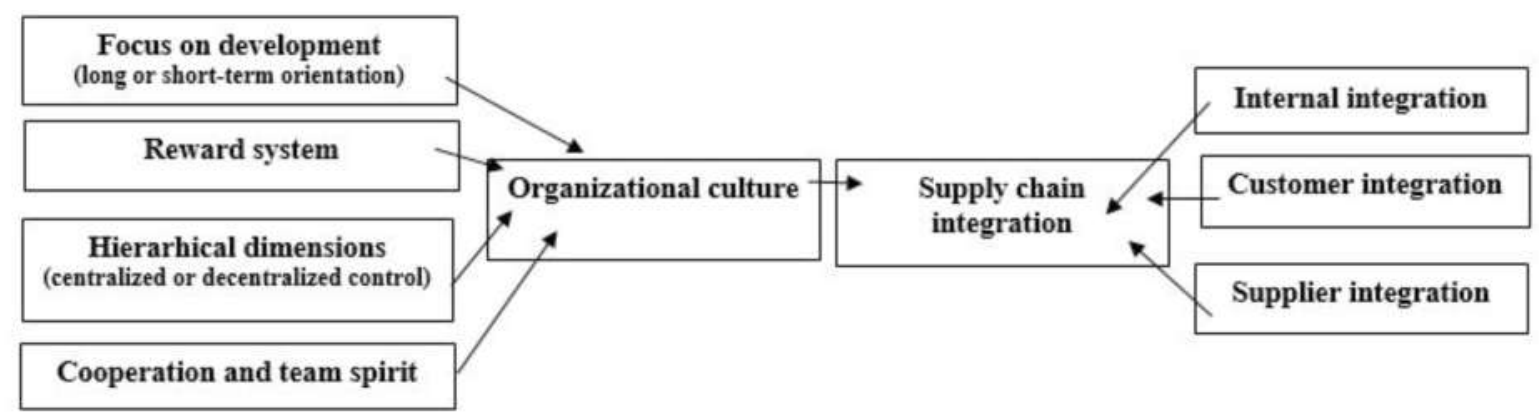

Figure 1. Starting model for the study of interdependence in the relation organizational culturesupply chain integration

Table 1. Profile of companies that participated in the survey $(n=328)$

\begin{tabular}{llcc}
\hline \multicolumn{1}{c}{ Profile of companies } & Number of companies (n) & Precentage (\%) \\
\hline $\begin{array}{l}\text { Company size according to the } \\
\text { criteria of the Business }\end{array}$ & Small enterprises & 94 & $29 \%$ \\
$\begin{array}{l}\text { Registers Agency of the } \\
\text { Republic of Serbia }\end{array}$ & Medium enterprises & 151 & $46 \%$ \\
\hline & Large enterprises & 83 & $25 \%$ \\
\hline \multirow{3}{*}{ Market experience } & under 10 years & 88 & $27 \%$ \\
& 10-20 years & 115 & $35 \%$ \\
& over 20 years & 125 & $38 \%$ \\
\hline \multirow{3}{*}{ Sector of the economy } & Manufacturing sector & 165 & $50 \%$ \\
& Trade sector & 75 & $23 \%$ \\
& Service sector & 88 & $27 \%$ \\
\hline & Belgrade & 85 & $26 \%$ \\
& Vojvodina & 62 & $19 \%$ \\
Region of Serbia & Sumadija & 45 & $14 \%$ \\
& Western Serbia & 55 & $16 \%$ \\
& Eastern Serbia & 38 & $12 \%$ \\
& Southern Serbia & 43 & $13 \%$
\end{tabular}

companies in the service $(27 \%)$ and trade sectors of the economy (23\%). The largest number of surveyed companies is based in Belgrade (26\%), followed by Vojvodina $(19 \%)$ and Western Serbia (16\%).

IBM statistical software SPSS was used to analyze the collected data. Descriptive, correlation and regression statistical analysis were applied. First, a descriptive statistical analysis was conducted on the entire sample of respondents with the aim of assessing the level of homogeneity of respondents' attitudes regarding the dimensions of organizational culture in medium and large enterprises in the Republic of Serbia, as well as the level of supply chain integration. In the second step, a correlation statistical analysis was performed in order to consider the existence of a correlation between all variables presented in Figure 1, as well as the strength of the relationship between each of them. Regression analysis, as a final step, aims to identify the dimensions of organizational culture with the greatest impact at each of the levels of supply chain integration: internal integration, integration 
with customers and integration with represented in Serbian companies. The suppliers. values of the standard deviation range from $0.640-1.464$, which indicates the relative homogeneity of attitudes regarding the

4. RESULTS OF THE STATISTICAL ANALYSIS dimensions of organizational culture. Representatives of the surveyed companies in the Republic of Serbia, by filling out the questionnaire, presented the four most common characteristics of organizational

The obtained results of the descriptive statistics are shown in Tables 2 and 3. By implementing the descriptive statistical analysis, the arithmetic mean and standard deviation for each of the statements were calculated.

Table 2 shows the results of the descriptive statistics for the statements related to the dimensions of the organizational culture. All findings were rated with average grades, which implies that the specifics of each of the dimensions of organizational culture are moderately culture in Serbian companies in the manufacturing, trade and service sectors:

- There are clearly defined rules and procedures (mean 4.32), which are explained by the fact that all companies strive to meet the requirements of the Quality Management System.

- Coordination of activities is carried out by the top management in companies (mean 4.20).

- Competition moves are actively monitored with the aim of quick and efficient response to them because it is a key

Table 2. Results of the descriptive statistical analysis- dimensions of organizational culture

\begin{tabular}{|c|c|c|c|}
\hline \multicolumn{2}{|c|}{ The statements - refer to the dimensions of organizational culture } & \multirow{2}{*}{$\begin{array}{c}\text { Mean } \\
3.94\end{array}$} & \multirow{2}{*}{$\begin{array}{c}\begin{array}{c}\text { Std. } \\
\text { deviation }\end{array} \\
0.640\end{array}$} \\
\hline \multirow{4}{*}{$\begin{array}{c}\text { Focus on } \\
\text { development }\end{array}$} & Monitoring competitors' moves & & \\
\hline & Prediction of potential new technologies & 3.42 & 0.686 \\
\hline & Implementation of modern technologies & 3.61 & 0.770 \\
\hline & Thinking about a new genaration of technologies & 3.60 & 0.697 \\
\hline \multirow{4}{*}{$\begin{array}{l}\text { Reward } \\
\text { system }\end{array}$} & Reward system positively influences achieving targets & 3.47 & 0.957 \\
\hline & Fair rewarding of employees & 3.25 & 0.960 \\
\hline & Recognition of the right people in the company & 3.07 & 0.863 \\
\hline & Reward system stimulates employees & 3.25 & 0.894 \\
\hline \multirow{4}{*}{$\begin{array}{l}\text { Hierarhical } \\
\text { dimensions }\end{array}$} & There are clearly defined rules and procedures & 4.32 & 0.807 \\
\hline & Coordination from the top of the company & 4.20 & 0.794 \\
\hline & Each decision needs to have the approval of the manager & 3.47 & 1.437 \\
\hline & Power arises from a position in the organizational structure & 3.60 & 1.464 \\
\hline \multirow{4}{*}{$\begin{array}{l}\text { Cooperation } \\
\text { and team spirit }\end{array}$} & Teamwork among employees & 3.67 & 0.957 \\
\hline & Freedom of decision and control over work tasks & 3.40 & 0.960 \\
\hline & Exchange of opinion and ideas among employees & 3.67 & 0.863 \\
\hline & Managers stimulate discussion among employees & 3.58 & 0.894 \\
\hline
\end{tabular}

Source: Authors' calculations 
prerequisite for survival and success in the market (mean 3.94) and

- Companies strive to stimulate teamwork, exchange of opinions and ideas among employees (mean 3.67).

The biggest shortcoming of the organizational culture represented in Serbian companies was the ability to recognize the right people and stimulate their potential through a reward system (lowest average score 3.07). The reward system, as a dimension of organizational culture, received the lowest marks from the representatives of the surveyed companies. They said that a fair system of rewarding employees was moderately represented in Serbia, which discourages employees from giving their best within their workplace.

The results of the descriptive statistics for findings related to supply chain integration levels are shown in Table 3. Each of the levels was rated with average scores, ranging from 3.44-3.81. The surveyed companies stated that they pay most attention to building long-term partnerships with customers (mean 3.81) and suppliers (mean
3.76). The focus on quickly and efficiently resolving customer complaints, with the aim of generating their satisfaction and loyalty, was also highly rated (mean 3.75 ). When it comes to the internal level of supply chain integration, companies in Serbia pay the most attention to stimulating intensive communication (3.72) and teamwork (3.58) between organizational units. The values of the standard deviation range from 0.597 0.915, which indicates the relative homogeneity of attitudes regarding the importance that the surveyed companies give to the levels of supply chain integration.

After conducting a descriptive statistical analysis, an analysis was conducted of the reliability of the findings defined for each of the dimensions of organizational culture, as well as the findings related to the levels of integration of the supply chain. The analysis was performed by the method of Cronobach alpha coefficient, with values ranging from 0 to 1 , with the recommendation that the confidence threshold should not be less than 0.7 (Leech et al., 2005), which is not violated in this study (Table 4). A high value of

Table 3. Results of the descriptive statistical analysis-supply chain integration levels

\begin{tabular}{|c|c|c|c|}
\hline \multicolumn{2}{|c|}{ The statements - refer to supply chain integration levels } & \multirow{2}{*}{$\begin{array}{c}\text { Mean } \\
3.72\end{array}$} & \multirow{2}{*}{$\begin{array}{c}\text { Std. deviation } \\
0.699\end{array}$} \\
\hline \multirow{4}{*}{$\begin{array}{l}\text { Internal } \\
\text { integration }\end{array}$} & Intensive communication between organizational parts & & \\
\hline & Team spirit between organizational parts & 3.58 & 0.915 \\
\hline & Coordination of organizational parts & 3.51 & 0.782 \\
\hline & Joint problem solving & 3.44 & 0.865 \\
\hline \multirow{3}{*}{$\begin{array}{l}\text { Customer } \\
\text { integration }\end{array}$} & $\begin{array}{l}\text { Monitoring customer requirements and adjusting products } \\
\text { /services with them }\end{array}$ & 3.67 & 0.678 \\
\hline & Quick response to customer complaints & 3.75 & 0.603 \\
\hline & $\begin{array}{l}\text { Involvement of customers in improving the quality of } \\
\text { products/services }\end{array}$ & 3.45 & 0.678 \\
\hline \multirow{5}{*}{$\begin{array}{l}\text { Supplier } \\
\text { integration }\end{array}$} & Focus on developing long-term partnerships with customers & 3.81 & 0.656 \\
\hline & Monitoring supplier requirements & 3.81 & 0.650 \\
\hline & Involvement of suppliers in quality improvement & 3.44 & 0.665 \\
\hline & $\begin{array}{l}\text { Focus on problem solving in business cooperation with } \\
\text { suppliers }\end{array}$ & 3.67 & 0.715 \\
\hline & Focus on developing long-term partnerships with suppliers & 3.76 & 0.597 \\
\hline
\end{tabular}


Cronobach alpha coefficients was found for all variables (values range from 0.7730.974), which indicates the existence of a high degree of reliability of all findings defined as a starting point in the study for each of the variables.

\subsection{Correlation analysis}

After the descriptive statistical analysis and analysis of reliability of findings, a correlation statistical analysis was conducted with the aim of considering the relationship between all variables that are the subject of research, i.e. the relationship between the dimensions of organizational culture - levels of supply chain integration in the production, trade and service sector. The obtained results are presented in Table 5.

The results of the correlation statistical analysis, presented within Table 5, have shown that there is a statistically significant correlation between all dimensions of organizational culture and the level of supply chain integration. All statistically significant correlations were denoted by $* *$ (** denotes $p<0.01)$. Guided by Cohen's recommendation to determine the strength of the correlation between variables (Cohen, 1988), we can conclude that a strong positive correlation ( $r=0.50$ to 1$)$ exists between all dimensions of the organizational culture and supply chain integration levels, except hierarchical dimensions that negatively correlate with integration levels, but in terms of values, this correlation, according to

Table 4. Cronbach alpha coefficient values for all variables

\begin{tabular}{lc}
\hline \multicolumn{1}{c}{ Variable } & Cronobach's alpha \\
\hline Focus on development & 0.932 \\
Reward system & 0.969 \\
Hierarhical dimensions & 0.773 \\
Cooperation and team spirit & 0.974 \\
Internal integration & 0.965 \\
Customer integration & 0.936 \\
Suplier integration & 0.940 \\
\hline Source: Authors' calculations &
\end{tabular}

Table 5. Results of correlation statistical analysis

\begin{tabular}{|c|c|c|c|c|c|c|c|}
\hline & $\begin{array}{c}\text { Focus on } \\
\text { development }\end{array}$ & $\begin{array}{l}\text { Reward } \\
\text { system }\end{array}$ & $\begin{array}{l}\text { Hierarhical } \\
\text { dimensions }\end{array}$ & $\begin{array}{l}\text { Cooperation } \\
\text { and team spirit }\end{array}$ & $\begin{array}{c}\text { Internal } \\
\text { integration }\end{array}$ & $\begin{array}{l}\text { Customer } \\
\text { integration }\end{array}$ & $\begin{array}{l}\text { Supplier } \\
\text { Integration }\end{array}$ \\
\hline $\begin{array}{l}\text { Focus on } \\
\text { development }\end{array}$ & 1 & $0.743^{* *}$ & -0.094 & $0.837^{* *}$ & $0.813^{* *}$ & $0.894^{* *}$ & $0.901^{* * *}$ \\
\hline Reward system & $0.743^{* *}$ & 1 & $-0.360^{* *}$ & $0.911^{* *}$ & $0.901^{* * *}$ & $0.825^{* *}$ & $0.829^{* * *}$ \\
\hline $\begin{array}{l}\text { Hierarhical } \\
\text { dimensions }\end{array}$ & -0.094 & $-0.360^{* *}$ & 1 & $-0.321^{* *}$ & $-0.234^{* * *}$ & $-0.151^{* *}$ & $-0.135^{* *}$ \\
\hline $\begin{array}{l}\text { Cooperation } \\
\text { and team spirit }\end{array}$ & $0.837^{* *}$ & $0.911^{* *}$ & $-0.321^{* *}$ & 1 & $0.903^{* *}$ & $0.894^{* *}$ & $0.898^{* *}$ \\
\hline $\begin{array}{l}\text { Internal } \\
\text { integration }\end{array}$ & $0.813^{* *}$ & $0.901^{* *}$ & $-0.234^{* * *}$ & $0.903^{* *}$ & 1 & $0.937^{* *}$ & $0.940^{* * *}$ \\
\hline $\begin{array}{l}\text { Customer } \\
\text { integration }\end{array}$ & $0.894^{* *}$ & $0.825^{* *}$ & $-0.151^{* *}$ & $0.894^{* *}$ & $0.937^{* *}$ & 1 & $0.994^{* *}$ \\
\hline $\begin{array}{l}\text { Supplier } \\
\text { integration }\end{array}$ & $0.901^{* *}$ & $0.829^{* *}$ & $-0.135^{* *}$ & $0.898^{* *}$ & $0.940^{* *}$ & $0.994^{* *}$ & 1 \\
\hline
\end{tabular}


Colton (1974), is considered a weak negative correlation ( $r$ ranges from -0.135 to -0.234 ).

The conducted correlation analysis also indicated the existence of a strong positive relationship between certain dimensions of organizational culture (focus on development, reward system and cooperation / team spirit), as well as between all levels of supply chain integration ( $r$ ranges from 0.743-0.994). The only statistically insignificant correlation was identified in the relation of hierarchical dimension- focus on development because the surveyed companies expressed the opinion that centralized management and control do not affect the focus on innovation and development. Hierarchical dimensions statistically significantly, but negatively, correlate with the reward system $(r=-0.360)$ and cooperation/ team spirit $(r=-0.321)$. Representatives of the surveyed companies in Serbia expressed the opinion that centralized control does not have a positive effect on recognizing the right people, fair rewards and stimulating teamwork among employees. Precisely this negative correlation spilled over into the negative impact of the hierarchical dimensions of organizational culture on internal integration, integration with suppliers and integration with customers.

\subsection{Regression statistical analysis}

Conducting the regression statistical analysis, after correlation, aims to identify the dimensions of organizational culture with the greatest impact on each of the levels of supply chain integration. By analyzing the preconditions for conducting the regression analysis, it was concluded that the existence of multicollinearity requires the modification of a set of independent variables. The existence of a high correlation between the independent variables reward system and cooperation/team spirit $(r=0.901)$ shows that they actually "measure" the same phenomenon. The answers of the representatives of the companies in Serbia have shown that the system of rewarding and recognizing the right people determines the stimulation of teamwork and the exchange of opinions of employees. In order to solve the problem of multicollinearity, the variable coordination/team spirit was excluded (because it is determined by the reward system) and three regression analyses were performed in which the following dimensions of organizational culture have the status of independent variables: focus on development, reward system and hierarchical dimensions.

First, a regression analysis was performed in which the internal integration of the supply chain has the status of a dependent variable. The results have shown that the model formed in this way explains as much as $85.9 \%$ of the variance of the dependent variable $\left(R^{2}=0.859 ; F(3,327)=660,024\right.$; $p<0.01)$. Table 6 shows the regression coefficients for this model.

Based on the statistical significance of $t$ tests for regression coefficients of this linear model, it can be seen that a significant contribution to the prediction of internal integration of the supply chain of enterprises in the Republic of Serbia has focus on development and reward system as dimensions of organizational culture $(p<0.01)$. These are the predictors with the statistically most significant impact on communication, coordination and teamwork among the organizational parts of enterprises in the manufacturing, trade and service sectors in Serbia. Regression analysis confirmed the results of a correlation 
Table 6. Overview of regression coefficients- internal supply chain integration as a dependent variable

\begin{tabular}{|c|c|c|c|c|c|}
\hline & \multicolumn{2}{|c|}{$\begin{array}{l}\text { Unstandardized } \\
\text { Coefficients }\end{array}$} & \multirow{2}{*}{$\begin{array}{c}\text { Standardized } \\
\text { Coefficients }\end{array}$} & \multirow[t]{2}{*}{$\mathbf{t}$} & \multirow[t]{2}{*}{ Sig. } \\
\hline & B & $\begin{array}{l}\text { Std. } \\
\text { Error }\end{array}$ & & & \\
\hline (Intercept) & 0.182 & 0.536 & & 0.339 & 0.734 \\
\hline Focus on development & 0.371 & 0.040 & 0.304 & 9.381 & 0.000 \\
\hline Reward system & 0.613 & 0.031 & 0.691 & 20.006 & 0.000 \\
\hline Hierarhical dimensions & 0.043 & 0.023 & 0.043 & 1.848 & 0.066 \\
\hline
\end{tabular}

Table 7. Overview of regression coefficients - integration with customers as a dependent variable

\begin{tabular}{lccccc}
\hline & \multicolumn{2}{c}{$\begin{array}{c}\text { Unstandardized } \\
\text { Coefficients }\end{array}$} & $\begin{array}{c}\text { Standardized } \\
\text { Coefficients }\end{array}$ & t & Sig. \\
& B & $\begin{array}{c}\text { Std. } \\
\text { Error }\end{array}$ & Beta & & \\
\cline { 1 - 4 } (Intercept) & 2.223 & 0.420 & & 5.288 & 0.000 \\
Focus on development & 0.577 & 0.031 & 0.609 & 18.621 & $\mathbf{0 . 0 0 0}$ \\
Reward system & 0.268 & 0.024 & 0.389 & 11.143 & $\mathbf{0 . 0 0 0}$ \\
Hierarhical dimensions & 0.036 & 0.018 & 0.046 & 1.959 & 0.051 \\
\hline Source: Authors' calculations & & & & &
\end{tabular}

analysis on the existence of a strong relationship between these variables.

In the next step, a regression analysis was performed in which integration with customers, as the level of supply chain integration, has the status of a dependent variable. Independent variables are dimensions of organizational culture: focus on development, reward system and hierarchical dimensions. The results have shown that the model formed in this way explains as much as $85.9 \%$ of the variance of the dependent variable $\left(R^{2}=0.859\right.$; $F(3,327)=645,393 ; p<0.01)$. Table 7 shows the regression coefficients for this model.

Table 8 presents the existence of a statistically significant impact of focus on development and reward system on integration with customers as the level of supply chain integration $(p<0.01)$. These are the same variables that have a statistically significant impact on internal integration. Given that correlation analysis presented the existence of a strong correlation between internal integration and integration with customers ( $r=0.937)$, it is not surprising that the same dimensions of organizational culture have the greatest impact on these levels of supply chain integration.

In the third step, a regression analysis was performed with the same independent variables as in the previous two cases, with the proviso that in this analysis integration with suppliers, as the third level of supply chain integration, has the status of a dependent variable. The results have shown that the model formed in this way explains as much as $87.3 \%$ of the variance of the dependent variable $\left(R^{2}=0.873\right.$; $F(3,327)=742,043 ; p<0.01)$. Table 8 shows 
Table 8. Overview of the regression coefficients - integration with suppliers as a dependent variable

\begin{tabular}{lccccc}
\hline & \multicolumn{2}{c}{$\begin{array}{c}\text { Unstandardized } \\
\text { Coefficients }\end{array}$} & $\begin{array}{c}\text { Standardized } \\
\text { Coefficients }\end{array}$ & t & Sig. \\
\cline { 1 - 4 } & $\mathbf{B}$ & $\begin{array}{c}\text { Std. } \\
\text { Error }\end{array}$ & Beta & & \\
\cline { 1 - 3 } (Intercept) & 1.802 & 0.396 & & 4.550 & 0.000 \\
Focus on development & 0.580 & 0.029 & 0.611 & 19.852 & $\mathbf{0 . 0 0 0}$ \\
Reward system & 0.275 & 0.023 & 0.399 & 12.168 & $\mathbf{0 . 0 0 0}$ \\
Hierarhical dimensions & 0.052 & 0.017 & 0.066 & 2.993 & $\mathbf{0 . 0 0 3}$ \\
\hline Source: Authors' calculations & & & & &
\end{tabular}

the regression coefficients for this model.

The results of the third regression crystallized a statistically significant impact of the same dimensions of organizational culture as the previous two, with hierarchical dimensions proving to be a statistically significant determinant of integration with suppliers, but to a lesser extent in focus on development and reward system. The results of the correlation analysis showed that hierarchical dimensions have a negative relationship with all levels of supply chain integration, while other dimensions of organizational culture have a positive relationship.

It can be concluded that the focus on development and reward system, as dimensions of organizational culture, are statistically important predictors of internal integration, integration with customers and integration with suppliers. These variables have a positive impact on all levels of supply chain integration, which was simultaneously confirmed by the results of correlation and regression analysis.

\section{COMMENTS ON THE CONDUCTED STATISTICAL ANALYSIS}

The results of the conducted descriptive, correlation and regression statistical analysis are the basis for making a final judgment on the initial research hypotheses:

- Development orientation, as a dimension of organizational culture, affects the supply chain integration (internal integration, integration with suppliers and integration with customers) - fully accepted hypothesis $\mathrm{H} 1$. The results of the correlation analysis indicated the existence of a statistically significant correlation between development orientation and each of the levels of supply chain integration. Regression analysis proved a statistically significant positive impact of this dimension of organizational culture on all levels of supply chain integration, which confirmed the result of the previous studies on this topic. Therefore, the focus on monitoring and implementation of innovations in the field of technology is one of the key determinants of efficient integration of the supply chain of companies in the Republic of Serbia. Responding to competition and implementing new technologies is the key to efficient integration of processes, not only in one company, but also processes along the entire supply chain, thus contributing to the effective achievement of the supply chain management goal of delivering quality product to the right place at the right time at an acceptable cost.

- The reward system, as a dimension of 
organizational culture, affects the integration of the supply chain (internal integration, integration with suppliers and integration with customers) - fully accepted hypothesis $\mathrm{H} 2$. The results of correlation and regression analysis indicated the existence of a statistically significant impact of recognizing the right people in the organization and fairly rewarding them on the efficiency of all levels of supply chain integration. The reward system is an important factor in stimulating employees to greater commitment in the workplace, which directly affects the effective coordination and teamwork of organizational parts of the company, and the interest of employees to contribute to generating customer and supplier satisfaction and building long-term partnerships with them.

- Hierarchy, as a dimension of organizational culture, influences supply chain integration (internal integration, integration with suppliers and integration with customers) - confirmation of hypothesis H3. Hierarchical dimensions of organizational culture, unlike other dimensions, have a negative correlation with all levels of supply chain integration. The values of the correlation coefficients indicate $(r<-0.5)$ that the negative correlations of centralized decision-making/control and each of the levels of supply chain integration are not statistically strong. The slight negative impact of centralized decisionmaking/control was confirmed by regression analysis, where it was shown that hierarchical dimensions have a statistically significant impact only on integration with suppliers, but this impact is lesser compared to other dimensions of organizational culture. Position as a source of power in the company and centralized control/decisionmaking discourages employee commitment in the workplace, negatively affecting teamwork and exchange of opinions and ideas, which directly negatively affects the coordination and teamwork between organizational parts of the company, and the commitment of employees to build and maintaining long-term partnerships with customers and suppliers.

- Teamwork, as a dimension of organizational culture, affects the supply chain integration (internal integration, integration with suppliers and integration with customers) - confirmed hypothesis H4. The results of the correlation analysis crystallized a statistically significant correlation between teamwork and each of the levels of supply chain integration. Teamwork, exchange of opinions/ideas and independent decision-making/control over work tasks have a very positive effect on the efficient conduct of the process, not only in the company, but along the entire chain. The surveyed companies in Serbia agree that there is a significantly strong correlation between the reward system and teamwork $(r=0.901)$, which is a consequence of the fact that fair rewarding is the basic stimulus for teamwork and commitment of all organizational parts. That is why the analysis of preconditions for conducting the regression analysis has shown that these two variables in the same way measure each of the levels of supply chain integration.

- Organizational culture is a significant predictor of generating efficient supply chain integration - H5 hypothesis confirmed. The results of the correlation and regression analysis presented the impact of each of the dimensions of organizational culture on each of the levels of supply chain integration, which directly leads to the conclusion that organizational culture is an important determinant of generating the key goal of 
supply chain management. and at reasonable cost.

It can be concluded that the specifics of the organizational culture of the company significantly determine the integration of the supply chain, one of the key qualitative indicators of business performance. The business practice of companies in the Republic of Serbia has shown that organizational culture, oriented towards decentralized decision-making/control, monitoring and implementation of new technologies, fair remuneration of employees and stimulating their teamwork, is the key to efficient integration of processes throughout the supply chain. Centralized decision-making/control and power arising from the position in the organizational structure discourages employees from commitment in the workplace and teamwork among them, which negatively affects the coordination and teamwork of organizational parts of the company, as well as the contribution of employees in generating satisfaction and building long-term partnerships, relationships with suppliers and customers, as partners in the supply chain.

\section{THEORETICAL/PRACTICAL IMPLICATIONS, RESEARCH LIMITATIONS AND FURTHER LINES OF RESEARCH}

The scientific contribution of this paper is reflected in a more detailed clarification of the interdependence in relation to the dimension of organizational culture - levels of supply chain integration. The results of the research are the basis for making relevant theoretical and practical conclusions about the impact of each dimension of organizational culture on the efficiency of supply chain integration, as one of the key qualitative indicators of business performance of any company. This topic has attracted the attention of foreign researchers more than the ones in national circles. Accordingly, the presented research can significantly contribute to overcoming the identified research gap.

The study can also provide significant practical contributions in terms of the implementation of the acquired knowledge. The research is based on the business practice of companies from the domain of all economic sectors of the Republic of Serbia, which makes the obtained results relevant. Company managers, using the results of the study, can get practical guidance on what needs to be corrected and improved in the specifics of organizational culture in order to stimulate innovation, teamwork and commitment of employees to contribute to efficient integration of all processes along the supply chain performance.

The essential scientific and practical contribution of the paper is reflected in the creation of empirically supported evidence that the specifics of organizational culture are an important determinant of efficient supply chain integration and generating the key goal of supply chain management which is the delivery of the right product, at the right place, at the right time and at reasonable cost.

The main limitation of this paper is reflected in the way of collecting the data that served as the basis for the research, which is based on the views of one of the employees in the companies. The question is how impartial the views are and the fact is that the views of one representative will not fully reflect the real situation in a particular company. Surveying a larger number of employees, at different organizational levels, 
in each of the companies, would contribute to removing this limitation and creating a more realistic picture of the impact of organizational culture on the supply chain integration. A limitation of this paper is also the observation of the dimensions of organizational culture as static variables. What would significantly improve a research on this topic, and at the same time neutralize this limitation, is to monitor the evolution of the dimensions, with an analysis of the positive or negative impact of evolution on internal integration, integration with customers and integration with suppliers. Future research should move in this direction, with a focus on removing these limitations, with the aim of deeper research into the interdependence of organizational culture and supply chain integration and a stronger link between qualitative and quantitative research on this topic.

\section{CONCLUSION}

Organizational culture as an element of organizational design has the status of an important determinant of generating efficient supply chain integration. The dimensions of organizational culture have a statistically significant correlation with each of the levels of supply chain integration: internal integration, integration with customers and integration with suppliers. The business practice of companies in the Republic of Serbia presented the greatest impact of decentralized management/control, monitoring/implementation of new technologies, recognition /evaluation of the right people in companies and fair reward system as key features of organizational culture that stimulate employees to greater commitment in the workplace, improving quality and building long-term partnerships with suppliers and customers. The focus on development and the reward system have crystallized as dimensions of organizational culture with the greatest impact on generating the key goal of establishing efficient and effective supply chain management which is delivering the right product, to the right place, at the right time and at reasonable cost. This study confirmed the results of previous research on the interdependence of organizational culture and supply chain integration, with relevant evidence that this interdependence is one of the key determinants of improving business performance of companies in the production, trade and service sectors of the economy.

\section{References}

Alsurideh, M., Alsharari, N., \& Kurdi, B. (2019). Supply Chain Integration and Customer Relationship Management in the Airline Logistics. Theoretical Economics Letters, 9(2), 392-414.

Amoako-Gyampah, K., Boakye, K.G., Adaku, E., \& Famiyeh, S. (2019). Supplier relationship management and firm performance in developing economies: A moderated mediation analysis of flexibility capability and ownership structure. International Journal of Production Economics, 208 (c), 160-170.

Badawy, T., Trujillo-Reyes, J., \& Magdy, M. (2016). Exploring the Relationship between Organizational Culture, Organizational Citizenship Behavior and Job Satisfaction: A Comparative Study between Egypt and Mexico. International Journal of Management and Administrative Sciences, 4 (6), 1-15.

$$
\text { Bagchi, P.K., Chun Ha, B., Skjoett- }
$$




\title{
УТИЦАЈ ОРГАНИЗАЦИОНЕ КУЛТУРЕ НА ИНТЕГРАЦИЈУ ЛАНЦА СНАБДЕВАЊА
}

\author{
Слободан Аћимовић, Вељко М. Мијушковић, Ана Тодоровић Спасенић
}

\begin{abstract}
Извод
Тим запослених који тежи остварењу заједничког циља је оно што је потребно свакој компанији, а успех пословања зависи од начина функционисања и размишљања тог тима. Организациона култура обликује начин на који запослени размишљају, реагују и понашају се. Пословна пракса предузећа у Републици Србији показала је да је организациона култура оријентисана на запослене, акцију и изазове важна одредница побољшања свих показатеља пословног учинка, укључујући интеграцију ланца снабдевања, што је главна тема анализе у овом раду. Димензије организационе културе утичу на унутрашњу интеграцију, интеграцију са купцима и интеграцију са добављачима, одређујући остваривање кључног циља управљања ланцем снабдевања који се односи на испоруку правог производа, на право место, у право време и уз разумне трошкове.
\end{abstract}

Кључне речи: организациона култура, интеграција ланца снабдевања, Република Србија

Larsen, T., \& Boege Sørensen, L. (2005). Supply chain integration: a European survey. International Journal of Logistics Management, 16 (2), 275-294.

Barney, J. (1980). Organizational Culture: Can it be a source of sustained competitive advantage, University of California, Los Angeles.

Braunscheidel, M., Suresh, N., \& Boisnier, A. (2010). Investigating the impact of organizational culture on supply chain integration. Human Resource Management, 49 (5), 883-911.

Cameron, K., \& Quinn, R. (2011). Diagnosing Changing Organizational Culture: Based on the Competing Values Framework (3rd ed.). Jossey-Bass A Wiley Imprint. Hoboken, NJ.

Cao, Z., Huo, B., Li, H., \& Zhao, X. (2015). The impact of organizational culture on supply chain integration: a contingency and configuration approach. Supply Chain
Management: An International Journal, 20 (1), $24-41$.

Chan, F., Samvedi, A., \& Chung, S.H (2015).Fuzzy time series forecasting for supply chain disruptions. Industrial Management \& Data Systems, 115 (3), 419435.

Chaudhuri, A., Boer, H., \& Taran, Y. (2018), Supply chain integration, risk management and manufacturing flexibility. International Journal of Operations \& Production Management, 38 (3), 690-712.

Cheng, Y., Chaudhuri, A., \& Farooq, S. (2016). Interplant coordination, supply chain integration, and operational performance of a plant in a manufacturing network: a mediation analysis. Supply Chain Management, 21 (5), 550-568.

Colton, T. (1974). Regression and correlation. Statistics in medicine, 189:218.

Cohen, J. (1988). Statistical Power Analysis for the Behavioral Sciences. 2nd 
ed. Erlbaum. Hillsdale, NJ.

Danese, P., \& Romano, P. (2011). Supply chain integration and efficiency performance: a study on the interactions between customer and supplier integration. Supply Chain Management, 16 (4), 220-230.

Denison, D., Nieminen, L., \& Kotrba, L. (2012). Diagnosing organizational cultures: A conceptual and empirical review of culture effectiveness surveys. European Journal of Work and Organizational Psychology, 23 (1), 145-161.

Denison, D.R., \& Spreitzer, G. (1991). Organizational culture and organizational development: a competing values approach. Research in Organizational Change and Development, 5 (1), 1-21.

Dubey, R., Gunasekaran, A., Childe, S.J., Papadopoulos, T., \& Helo, P. (2019). Supplier relationship management for circular economy: Influence of external pressures and top management commitment. Management Decision, 57 (4), 767-790.

Forkmann, S., Henneberg, S., Naude, P., \& Mitrega, M. (2016). Supplier relationship management capability: a qualification and extension. Industrial Marketing Management, 57, 185-200.

Gregory, B.T., Harris, S.G., Armenakis, A.A., \& Shook, C.L. (2009). Organizational culture and effectiveness: a study of values, attitudes, and organizational outcomes. Journal of Business Research, 62 (7), 673679.

Harrison, R, \& Stokes, H. (1992). Diagnosing Organizational Culture. Pfeiffer \& Company, San Francisco, USA.

Hartnell, C.A., Ou, A.Y., \& Kinicki, A. (2011). Organizational culture and organizational effectiveness: a meta-analytic investigation of the competing values framework's theoretical suppositions. Journal of Applied Psychology, 96 (4), 677-
694.

Huo, B., Qi, Y., Wang, Z., \& Zhao, X. (2014). The impact of supply chain integration on firm performance. Supply Chain Management: An International Journal, 19(4), 369-384.

Jacobs, M., Yu, W., \& Chavez, R. (2016). The effect of internal communication and employee satisfaction on supply chain integration. International Journal of Production Economics, 171 (1), 60-70.

Jambulingam, T., Kathuria, R., \& Nevin, J.R (2011). Fairness-trust-loyalty relationship under varying conditions of supplier-buyer interdependence. Journal of Marketing Theory and Practice, 19 (1), 3956.

Janićijević, N. (2008). Organizaciono ponašanje, Data Status, Beograd.

Kaur, M. (2009). Organizational Culture and Organizational Climate as a Determinant of Motivation. Journal of Management Research, 8 (10), 38-51.

Kim, D. (2013). Relationship between supply chain integration and performance. Operational Management Resources, 6, 7490.

Kim, T., \& Chang, J. (2019). Organizational culture and performance: a macro-level longitudinal study. Leadership \& Organization Development Journal, 40 (1), 65-84.

Koufteros, X.A., Vonderembse, M., \& Jayaram, J. (2005). Internal and external integration for product development: the contingency effects of uncertainty, equivocality, and platform strategy. Decision Sciences, 36 (1), 97-133.

Krajcsák, Z. (2018). Relationships between employee commitment and organizationalcultures: a theoretical framework. International Journal of Organizational Analysis, 26 (3), 398-414. 
Kucharska, W., \& Bedford, D. (2019). Knowledge Sharing and Organizational Culture Dimensions: Does Job Satisfaction Matter? Electronic Journal of Knowledge Management, 17 (1), 1-18.

Kumar, R. (2020). Supply Chain and Logistics Management: Concepts, Methodologies, Tools, and Applications. IGI Global, Pennsylvania, USA.

Leech, N. L., Barrett, K. C., \& Morgan, G. A. (2005). SPSS for Intermediate Statistics, Use and Interpretation. 2nd Edition, Lawrence Erlbaum Associates Inc., Mahwah.

Lee, C. W., Kwon, I. W. G., \& Severance, D. (2007). Relationship between supply chain performance and degree of linkage among supplier, internal integration, and customer. Supply Chain Management, 12 (6), 444-452.

Mandal, S. (2017). The influence of organizational culture on healthcare supply chain resilience: moderating role of technology orientation. Journal of Business \& Industrial Marketing, 32 (8), 1021-1037.

Muhlis, M., \& Prateep, W. (2019). The effects of culture and human resource management policies on supply chain management strategy. Polish Journal of Management Studies, 19 (1), 235-248.

Naor, M., Goldstein, S., Linderman, K., \& Schroeder R. (2008). The Role of Culture as Driver of Quality Management and Performance: Infrastructure Versus Core Quality Practices. Decision Sciences, 39, 671-702.

Nguyen, T., Nguyen, T., \& Pham, T. (2020). The effect of corporate entrepreneurship, organizational culture on supply chain management and business performance in chemical industry. Uncertain Supply Chain Management, 8 (1), 67-76.

Qi, Y., Huo, B., Wang, Z., Yan, H., \&
Yeung, J. (2017). The impact of operations and supply chain strategies on integration and performance. International Journal of Production Economics, 185, 162-174.

Pakurar, M., Haddad, H., Popp, J., Khan, T., \& Olah, J. (2019). Supply chain integration, organizational performance and balanced scorecard: an empirical study of the banking sector in Jordan. Journal of international studies, 2, 129-146.

Polychroniou, P., \& Trivellas, P. (2018). The impact of strong and balanced organizational cultures on firm performance: Assessing moderated effects. International Journal of Quality and Service Sciences, 10 (1), 16-35.

Ponnu, A., \& Hassan, Z. (2015). The Influences of Organizational Culture on Performance Management. International Journal of Accounting, Business and Management, 3 (1), 135-145.

Porter, M. (2019). Supply Chain Integration: Does Organizational Culture Matter? Operations and Supply Chain Management, 12 (1), 49-59.

Prajogo, D.I., \& McDermott, C. (2005). The relationship between total quality management practices and organizational culture. International Journal of Operations \& Production Management, 25 (11), 11011122.

Rezaei, E., Paydar, M.M., \& Safaei, A.S. (2020). Customer relationship management and new product development in designing a robust supply chain. RAIRO - Operations Research, 54 (2), 369-391.

Roscoe, S., Eckstein, D., Blome, C., \& Goellner, M. (2020). Determining how internal and external process connectivity affect supply chain agility: a life-cycle theory perspective. Production Planning \& Control, 31 (1), 78-91.

Sahay, B.S. (2003). Understanding trust 
in supply chain relationships. Industrial Management \& Data Systems, 103 (8), 553563.

Shih, C.-C., \& Huang, S.-J. (2010). Exploring the relationship between organizational culture and software process improvement deployment. Information and Management, 47, (5-6), 271-281.

Sikavica, P., Bahtijarević-Šiber, F., \& Pološki Vokić, N. (2008). Temelji menadžmenta, Školska knjiga Zagreb, Zagreb, Hrvatska.

Simchi-Levi, D., Kaminsky P., \& SimchiLevi, E. (2003). Designing \& Managing the Supply Chain. McGraw-Hill, New York.

Sokro, E. (2012). Analysis of the relationship that exists between organisational culture, motivation and performance. Problems of Management in the 21st Century, 3, 106-119.

Stock, G., McFadden, K., \& Gowen, C. (2007). Organizational culture, critical success factors, and the reduction of hospital errors. International Journal of Production Economics, 106 (2), 368-392.

Sung, H., \& Kim, S. (2019). The effect of organizational culture on supply chain management in uncertain environments. Asia Pacific Journal of Marketing and Logistics, 31 (4), 1003-1026.

Tarifa-Fernandez, J., \& De BurgosJiménez, J. (2017). Supply chain integration and performance relationship: a moderating effects review. International Journal of Logistics Management, 28 (4), 1243-1271.

Teller, C., Kotzab, H., Grant, D., \& Holweg, C. (2016). The importance of key supplier relationship management in supply chains. International Journal of Retail \& Distribution Management, 44 (2), 109-123.

Ullah, I., \& Narain, R. (2020). The Impact of Customer Relationship Management and Organizational Culture on
Mass Customization Capability and Firm Performance. International Journal of Customer Relationship Marketing and Management, 11 (13), 60-81.

Utami, P., \& Sitohang, M. (2019). Effect of organizational culture intensity on job satisfaction. Indonesian Journal of Health Administration, 7 (2), 116-122.

Walters, M., Dobson, P., \& Williams, A. (1989). Changing Culture. Institute of Personal Management, London, UK.

Wiengarten, F., Humphreys, P., Gimenez, C., \& Mclvor, R. (2016). Risk, risk management practices, and the success of supply chain integration. International Journal of Production Economics, 171, 361370.

Wong, C., Boon, S. \& Wong, C. (2011). The contingency effects of environmental uncertainty on the relationship between supply chain integration and operational performance. Journal of Operations Management, 29(6), 604-615.

Yilmaz, C., \& Ergun, E. (2008). Organizational culture and firm effectiveness: An examination of relative effects of culture traits and the balanced culture hypothesis in an emerging economy. Journal of World Business, 43 (3), 290-306.

Yunus, E., \& Tadisina, S. (2010). Organizational Culture Context, Supply Chain Integration and Performance. POMS 21st Annual Conference, Vancouver, Canada.

Zu, X., Robbins, T., \& Fredendall, L. (2010). Mapping the critical links between organizational culture and TQM/Six Sigma practices. International Journal of Production Economics, 123 (1), 86-106. 